Canadian University Music Review

Revue de musique des universités canadiennes

\title{
Erik Satie's Vexations-An Exercise in Immobility
}

\section{Christopher Dawson}

Volume 21, numéro 2, 2001

URI : https://id.erudit.org/iderudit/1014483ar

DOI : https://doi.org/10.7202/1014483ar

Aller au sommaire du numéro

\section{Éditeur(s)}

Canadian University Music Society / Société de musique des universités canadiennes

\section{ISSN}

0710-0353 (imprimé)

2291-2436 (numérique)

Découvrir la revue

Citer cet article

Dawson, C. (2001). Erik Satie's Vexations-An Exercise in Immobility. Canadian University Music Review / Revue de musique des universités canadiennes, 21(2), 29-40. https://doi.org/10.7202/1014483ar
Résumé de l'article

La pièce pour piano Vexations d'Erik Satie comporte une « Note de l'auteur » où le compositeur demande apparemment aux interprètes de répéter le morceau 840 fois. Les opinions des biographes de Satie divergent quant à savoir si Satie voulait ou non une exécution " complète " de la pièce. Dans cet article, l'auteur évalue comment une interprétation littéraire de la Note peut jeter un éclairage sur les intentions de Satie. Il conclut que Vexations n'est pas tant un morceau de bravoure qu'un exercice : un moment musical conçu pour dégager les interprètes des notions occidentales conventionnelles de développement linéaire et de réception cumulative, en faveur d'un style musical personnel d'où est absent le développement, et pour les préparer à jouer d'autres pièces, telles une Gymnopédie ou une Gnossienne.
All Rights Reserved (c) Canadian University Music Society / Société de musique des universités canadiennes, 2002
Ce document est protégé par la loi sur le droit d'auteur. L'utilisation des services d'Érudit (y compris la reproduction) est assujettie à sa politique d'utilisation que vous pouvez consulter en ligne.

https://apropos.erudit.org/fr/usagers/politique-dutilisation/ 


\title{
ERIK SATIE'S VEXATIONS-AN EXERCISE IN IMMOBILITY
}

\author{
Christopher Dawson
}

Whatever one's opinion of Vexations may be, or of Satie's intentions in writing it, it is certainly one of his most controversial and best remembered works. Its first "full" performance, given in New York in 1963 by a team of ten pianists headed by the composer John Cage, was met with intense media interest: the New York Times sent a team of eight critics to cover the performance, which lasted 18 hours and 40 minutes. This performance, which earned its performers amongst other things a place in the Guinness Book of Records, has since been followed by many other "full" performances around the world, ${ }^{1}$ establishing the work as one of the most significant forerunners of experimental music movement of the 1960s, and serving to characterize Satie - at least in the world of academia - as a composer whose achievement was primarily conceptual.

The piece itself is a single page of manuscript containing three lines of music: first a theme of 13 beats is presented containing every note of the chromatic scale except for A sharp / $G$ flat, then a harmonization involving 16 diminished triads in first inversion and one augmented triad also in first inversion, then an exact repetition of the original theme, and finally a second harmonization in which the disposition of the upper parts of the chord is inverted, making an overall structure of $A-A^{1}-A-A^{2}$. This technique of "varied repetition," combined with the chromatic nature of the theme (involving all but one of the nótes of the chromatic scale) and use of unresolved chords, serves to dissipate any sense of thematic progression and goal traditionally associated with Western compositional methods. For, as Robert Orledge has written,

Satie was not concerned with through-composition and the normal perception of music "getting somewhere" through functional forms and harmonies. [...] His concern lay in the way our perception of time could be expanded and telescoped, and how music could function as a spatial element in time. ${ }^{2}$

But what gives the piece its particular interest is an enigmatic playing instruction referred to as the Note de l'auteur:

1 For a list of most of the performances of this work up to 1979, see Gavin Bryars, "Vexations and its Performers," Contact 26 (1983): 12-20.

2 Robert Orledge, Satie the Composer (Cambridge: Cambridge University Press, 1990), 142-43. 
Pour se jouer 840 fois de suite ce motif, il sera bon de se préparer au préalable, et dans le plus grand silence, par des immobilités sérieuses.

This, if taken literally, means that the piece lasts between twelve and twentyfour hours, depending on the adopted tempo (which Satie marks très lent).

While none of Satie's biographers would describe John Cage's 1963 performance as being in any way invalid, they cannot be said to be of one opinion regarding Satie's intentions in writing the piece. Alan Gillmor, while viewing the work as an important precursor to the anti-teleological experimentation of John Cage and Leonard Meyer, entertains the possibility that it "just may be one of Satie's grandest leg-pulls."3 Marc Bredel sees Satie's aims as not so much conceptual as psychic. In referring to the period during which Vexations was written, he writes:

Il est plus que vraisemblable que Satie, au moins durant une certaine période de son existence, ait plus ou moins joué les apprentis sorciers avec tous les risques de déstabilations mentales que cela comporte. ${ }^{4}$

Peter Dickinson sees the possibility of a "full" performance whilst remaining on the fence regarding Satie's intentions:

Satie's intentions will never be known, but his jokes usually have serious undertones, and the fact that Cage, who has introduced the musical world to ideas familiar in other arts, felt common ground with Satie shows the earlier composer's prophetic power. ${ }^{5}$

Robert Orledge and Gavin Bryars are happier to entertain the possibility that Satie intended a "full" performance of the piece. Bryars, who himself performed the piece with Christopher Hobbs in Leicester in 1971, has described the work as a "Ring des Nibelungen des pauvres" ("a poor man's Ring of the Nibelungen"); 6 meanwhile Orledge, in his monograph Satie the Composer, states categorically:

It seems churlish to suggest that Satie did not know exactly what he was doing when he wrote Vexations. He probably envisaged a single performance taking one minute, with 840 repetitions taking exactly fourteen hours. Any shortfall was made up by the period of silent meditation recommended beforehand?

3 Alan Gillmor, "Satie, Cage, and the New Asceticism," Contact 25 (1982): 19. See also Alan Gillmor, Erik Satie (London: Macmillan, 1988), 103.

4Marc Bredel, Erik Satie (Paris: Éditions Mazarine, 1982), 79. It is interesting to compare this with Valerie Butler's remark as to why Peter Evans stopped his performance in Sydney in February 1970 after 595 repetitions: "He said he had to stop because his mind became full of evil thoughts, animals and 'things' started peering out at him from the score." See Bryars, "Vexations and its Performers," 16.

5Peter Dickinson, "Erik Satie," Music Review 28 (1967): 145.

6Bryars, "Vexations and its Performers," 12.

7 Orledge, Satie the Composer, 144. 
This lack of unanimity regarding Satie's intentions is more acute when one turns to composers who had strong links-personal or aesthetic-with Satie. Darius Milhaud and Henri Sauguet, both of whom were great friends and admirers of Satie, were opposed to a literal interpretation of the text, while John Cage and Rober Racine were convinced that Satie intended a "full" performance.

What these writers have in common, however, is that they have all arrived at their opinions, or decided not to offer one, on the basis of the musical evidence, that is to say through examination of the music, of its relation to Satie's musical ideas of the time and of its influence on later composers. There is, of course, nothing surprising in this as Satie's artistic reputation rests primarily on his musical output and legacy. But it is important to note that the whole notion of the "full" performance of 840 renditions of the motif has its basis not in the music (although the separation of the main body of the musical text and the bass theme does seem to hint at a measure of repetition) but in the written instruction accompanying the music. And that whilst accepting that musical instructions fall fully within the remit of musicology, there are certain aspects of the written text of Vexations that lend themselves to more literary forms of analysis. How then might a more literary interpretation of the Note throw light on Satie's intentions in writing the piece?

Most composers, however radical they may be in their musical approach, are content to view the musical instruction as simply a transparent means of putting forward technical information about a piece of music, whether it be in their own language or in the universal language of Italian. With Satie, however, the situation is different. From the Trois Gnossiennes of 1890 to the Sonatine bureaucratique of 1917 , Satie adorned his piano scores with enigmatic or eccentric instructions or commentaries of varying degrees of inscrutability. These instructions, for all their apparent eccentricity, are for the most part expressive, serving to communicate to the pianist an idea relating to the way in which the music should be played. ${ }^{8}$ In expressing this information in a non-direct manner Satie encourages his interpreters to reconstruct his thought processes and thereby get a more profound idea of his intentions, these relating as much to the spirit in which the piece is to be approached as to the precise technical manner in which a particular figure or passage is to be played.

In the light of this it seems very unlikely that Satie, even at as early a stage in his artistic development as 1892-3, would poke fun at his interpreters by presenting them with a totally false playing instruction. For all Satie's use of jesting as a means of attacking the music establishment (such as the three times during the 1890s that he presented his candidacy for the Institut de France), the idea of a hoax simply does not enter into the equation when one recognizes the importance that he attached to the composer-interpreter relationship. As Anne Rey writes: "Aux traditionnelles notations en italien, devenues lettre morte, Satie substitue son code secret, qui parfois ressemble à une devinette. Ainsi espère-t-il peut-être établir avec l'interprète un dialogue personnel, lui

8See Jean-Joël Barbier, Au Piano avec Erik Satie (Paris: Éditions Garamont-Archimbaud, 1986), 47. 
parler homme à homme."9 Also, according to Henri Sauget, Satie once described his annotations as "un secret entre l'interprète et moi." 10 Still less, therefore, was Satie likely to institute a hoax that would involve the sort of "vexations" engendered by a "full" performance of the piece. The leg-pull theory, then, according to which Vexations is nothing more than fumisterie or practical joking in the style of Alphonse Allais or a proto-Dada manifestation of anti-art, does not appear very convincing.

There are, however, certain factors weighing against the idea that Satie intended his Note to be taken literally. For example, one very strong authority on Satie, Darius Milhaud, felt that the composer would not have approved of a literal interpretation of his score, that his essential pudeur would not have allowed it. ${ }^{11}$ Furthermore, why, if Satie was so keen on extolling the virtues of pure monotony (as opposed to the relative monotony of Socrate), did he never take it upon himself to perform the piece? After all, there would have been little trouble in finding an audience from amongst his Rose-Croix or Dada comrades. However, I believe that the most revealing clues as to Satie's intentions-given that the music itself is non-conclusive and much of the other information concerning the piece circumstantial-lie in a close literary analysis of the written text. This involves three different processes: manuscript analysis (an area which of course overlaps with musicology), linguistic analysis and poetic analysis.

The first area of analysis of the Note pertains to its physical presence on the original manuscript. Although such manuscript analysis, which has been carried out by Gavin Bryars and Robert Orledge, has not proved conclusive, it has succeeded in raising interesting questions regarding Satie's intentions in writing the piece. For example, in his article "Vexations and its Performers," Gavin Bryars relates that on the manuscript of Vexations, the music is written in dark ink whilst the Note de l'auteur is written in lighter, watered-down ink. This has led him to conclude that "the sequence of composition [...] was first the music, then the title, and only afterwards the conditions under which it would be played." 12 Robert Orledge, however, disagrees with this assessment:

... as Satie would have been copying this final draft from a sketch (now lost), and because he often resorted to this economy measure [i.e. watering down his ink for the non-musical element of his manuscripts], there is no convincing proof that the music predates the conception of Vexations. Indeed, with the careful precautions against memorization built into the music, a reverse hypothesis would seem more likely. ${ }^{13}$

Although the difference in ink strengths in the manuscript certainly leaves open the possibility that the Note was conceived subsequent to the music, I would

9 Anne Rey, Erik Satie (Paris: Éditions du Seuil, 1974), 77.

10Barbier, Au Piano avec Erik Satie, 47.

11 See John Cage, Roger Shattuck, and Alan Gillmor "Erik Satie: A Conversation," Contact 25 (1982): 24.

12Bryars, "Vexations and its Performers," 12-13.

13Orledge, Satie the Composer, 144. 
agree with Orledge that the manuscript evidence is far from conclusive. However, I feel the idea regarding careful precautions against memorization is no more conclusive. The compositional and notational elements which make Vexations so hard to memorize are evident in other of Satie's works, although not quite in such a concentrated form. For example, many of his works dating from the 1890s are characterized by atonality or ametricality, whilst the device of spelling identical chords differently is present in Affolements grantitiques from Heures séculaires et instantanées as a means of creating humour. In any case, even if it could be proved that Satie intended to make the piece difficult to memorize, this could not be said to constitute conclusive evidence that Satie intended a "full" performance.

The remaining two forms of analysis relate to the more exclusively literary areas of language and imagery. A closer examination of the words used in the Note can throw up some interesting questions regarding Satie's intentions. The first interesting thing to note about the wording is his use of the reflexive verb se jouer (rather than the non-reflexive jouer). The reflexive form in French can be translated in various ways according to the context. For example sometimes it expresses an idea which is best rendered in English by the passive, as in $\grave{a}$ se jouer 840 fois which would be translated "to be played 840 times." However, the presence in the Note of the direct object ce motif makes the reflexive pronoun se necessarily indirect. This means that the initial clause must be translated either by "In order to play this motif to oneself 840 times in succession" or "In order to play for oneself this motif 840 times in succession" (of course, the word order can vary), both of which appear to suggest that Satie intended the piece to be performed alone. Bryars touches on this, but possibly not for the right reasons:

Nor do I agree with [Rober Racine's] interpretation of "se jouer" as implying the need for a large audience; it could equally apply to a performance for the player(s) alone.... ${ }^{14}$

I would be inclined to go further than Bryars and say that given the literal interpretation that has so often been given to the words 840 fois de suite in the clause, it is strange that so little attention has been paid to the implications of the se. (It is interesting to note that of all those who have given a "full" performance of Vexations, very few have been native French speakers.) Certainly when one views this idea in the light of the importance Satie attached to establishing a personal dialogue with the interpreter outside the earshot of the audience, it is very hard to rule out the possibility that Satie conceived of the piece as being played by the pianist alone.

Another interesting linguistic element is Satie's use of the word motif, rather than a more conventional term such as morceau. It is certainly true, as Bryars mentions, that a motif is "something that by nature returns time and time again." 15 However, it is equally true that a motif draws its power from being

14Bryars, "Vexations and its Performers," 17.

15 Ibid., 13. 
part of a larger work, and it may be that Satie is simply presenting us with a decontextualized fragment of music for aesthetic resonance (akin to his use of non-finite chords and motifs in many of his 1890 s works). Another point relates to his use of the adjectival complement $d$ 'usage in the note accompanying the bass theme À ce signe il sera d'usage de présenter le thème de la basse. While this is usually taken to mean "At this sign introduce the bass theme," its literal translation is, "At this sign it will be customary to introduce the bass theme," an ambiguous and somewhat eccentric choice of words implying a sense of repetition but without any sense of obligation. This ties in with the ambiguous syntactic structure of the main body of the Note which serves to throw a question mark over how serious or literal he is being when writing of repeating the piece 840 times (a matter I will address more fully a little later in this article).

A close examination of the literal meaning of the words making up the Note, then, can certainly throw up questions regarding previous interpretations of Satie's artistic intentions, but does not in itself lead to any definitive answers on the matter. However, in serving to question these more specifically musicological interpretations it does have the function of clearing the way for a more figurative interpretation of the Note, one that takes into account both Satie's tendency to use figurative language in his musical instructions as a means of conveying the spirit of his music in a more profound and intimate way, and his use of leitmotifs in his other forms of writing as a means of putting across his musical aesthetic.

If one were approaching the Note with no other knowledge of Satie's writings, one might be forgiven for feeling somewhat confused about the idea of preparing oneself for a piece of music "par des immobilités sérieuses." Depending on one's sense of humour, the idea might lie somewhere on a scale ranging from humorous to plain idiotic. A thorough knowledge of his writings, however, reveals that whatever one's own opinion may be, the idea of immobility is certainly one which tickled Satie. Take, for example, his statement in "La Journée du Musicien," 16 in which, as in the Note, he ironically presents immobility as one of his "occupations diverses": "Occupations diverses (escrime, réflexions, immobilité, visites, contemplation, dextérité, natation etc.): de 16 h 21 à 18 h $47 . "$

In the Danse cuirassée from Vieux Sequins et vieilles cuirasses, he employs a similar device when describing the "armoured dance" in question:

Se danse sur deux rangs. Le premier rang ne bouge pas. Le second rang reste immobile. Les danseurs reçoivent chacun un coup de sabre qui leur fend la tête.

And in Heures séculaires et instantanées he is sufficiently impressed by a character's "perpetual immobility" as to dedicate the work to him: $22-23$

16Ornella Volta, ed., Erik Satie: Écrits, rev. ed. (Paris: Éditions Champ Libre, 1981), no. 11, pp. 
A sir William Grant-Plumot, je dédie agréablement ce recueil. Jusqu'ici, deux figures m'ont surpris: Louis XI et sir William. Le premier, par l'étrangeté de sa bonhomie; le second, par sa continuelle immobilité. Ce m'est un honneur de prononcer, ici, les noms de Louis XI et sir William Grant-Plumot.

Although these references clearly function as a source of humour, helping to create the eccentric persona for which Satie is reknowned, I believe this motif to have a more serious, figurative meaning. The key to interpreting this motif lies in the identity of the curious Sir William figure, something which has confounded his biographers, from the very earliest to the very latest. For example, Rollo Myers, Satie's first English biographer, pleads total ignorance with the declaration: "As to the identity of 'Sir William' no clue is provided;"17 Alan Gillmor and Robert Orledge, though, are happier to speculate, suggesting respectively that he may have been related to Debussy's "Samuel Pickwick Esq., PPMPC" and that Sir William might have been a nickname for Shakespeare. ${ }^{18}$ The answer to this mystery lies, I believe, in the probable origins of Sir William as suggested by his name and title: his half French, half Scottish surname is surely a reference to Satie's own origins (his father was French and his mother was of Scottish extraction), whilst his status as a nobleman would tie in with Satie's imaginary opulence as described in articles such as "La Journée du musicien" and "Parfait entourage." 19 Thus it seems reasonable to suggest that in dedicating his Heures séculaires et instantanées to "Sir William Grant-Plumot," Satie is probably dedicating the work to himself, recalling the comment "Je me dédie cette œuvre" which appears in his Prélude de la Porte héroique du ciel of 1894.

Why, then, does he talk of Sir William's (that is, his own) "continuelle immobilité"? It is not hard, when examining Heures séculaires et instantanées, to see that the immobility mentioned in the dedication is linked with the theme of the work, which centers on the idea of time. On one level the theme is the conflict between heures séculaires and heures instantanées, that is between digital time (the "instantaneous hours" as represented by the ticking of a clock in the score) and time in the more general sense (the "age-old hours" as represented by the sun in the written text). This conflict is clearly illustrated in the text in the comment "l'ombre des arbres millénaires marque $9 \mathrm{~h} \mathrm{17"} \mathrm{and}$ the whole network of conflicts between and within the written text, the musical text and the musical score. But these conflicts point towards a more general theme, which is the problematic and restricting aspects of time, and by implication Satie's ultimate artistic solution: a form of music without a beginning or an end, one without direction or development, climax or conclusion, simply, as Jean-Joël Barbier says with regard to Heures séculaires et instantanées, "une musique hors du temps." 20

17Rollo Myers, Erik Satie (London: Dennis Dobson, 1948), 80.

18 See Gillmor, Erik Satie, 173, and Orledge, Satie the Composer, 306.

19 Volta, Erik Satie: Écrits, nos. 8 and 11.

20Barbier, Au Piano avec Erik Satie, 44. 
As with so many of Satie's instructions, the declaration in Heures séculaires et instantanées gives the interpreter an insight into the composer's aesthetic standpoint and shows the interpreter the way in which the piece should be approached. The piece, like the dedicatee, is "immobile;" that is to say it is developmentally static, a piece where motifs are juxtaposed and repeated, rather than one where themes are presented and developed. But a static piece need not imply stagnancy. From the mystical pieces of the 1890 s to the humoristic ones of the period 1913-16, Satie's anti-developmental techniques allowed him to achieve a fluidity in his works which seems to transcend the short duration of the music proper, as if the composer is showing only a snippet of a far longer work. Indeed, this is for Barbier the underlying meaning of Heures séculaires et instantanées:

On peut dire que l'immobilité des Gnossiennes donne, presque physiquement, la sensation du perpétuel.

Leur brièveté même implique une espèce d'éternité.

Au fond, ne serait-ce pas ce que sous-entend le titre, apparement énigmatique: "Heures séculaires et instantanées"?21

But in order to bring out this quality to an audience the interpreter must be fully aware of it to begin with, steadfastly avoiding Romantic conceptions of "grandeur" and time-bound declamation and replacing them with Satiean modesty and "pudeur."

What implications, then, might this information leave on the way in which we view the Note de l'auteur in Vexations? In "Erik Satie: A Conversation," John Cage expresses the opinion that in the Note, Satie is being completely serious:

Curiously enough, the textual remarks in connection with the Vexations are not humorous; they are in the spirit of Zen Buddhism. It says at the beginning of the piece not to play it until you have put yourself in a state of interior immobility, and it very clearly says that it is to be done 840 times. ${ }^{22}$

I would not entirely agree with this assessment for various reasons. To begin with, the structure of the sentence is such that it does not impart a clear meaning. Satie does not make a simple statement such as "À jouer 840 fois de suite," but prefers to put the information regarding the 840-fold repetition in a subordinate clause, as if it had already been mentioned or as if it went without saying that the piece should be repeated in this manner. This is of course not the case, and the effect is to throw a question over how serious he is being. Given the sentence structure, the reader's attention is directed towards the statement "il sera bon de se préparer par des immobilités sérieuses." Again I feel that clarity is lacking. The word "immobility" is not usually used countably in French or in English, and the effect is to give it something of the quality of 
a physical activity, rather like exercises carried out by athletes before the start of a race. As I have mentioned above, Satie creates a similarly absurd image in "La Journée du musicien," but he does so by juxtaposing the noun used uncountably with a list of more conventional occupations such as fencing and swimming. Satie's use of the adjective "sérieux" to qualify "immobilités" does little to clarify matters. Indeed, the more one becomes acquainted with Satie, the more one is inclined to be suspicious of any entreaties towards seriousness, or at least not to take them at face value. After all, this is the man who made comments such as “... D' aspect très sérieux, si je ris, c'est sans le faire exprès. Je m'en excuse toujours et avec affabilité," 23 or "... Mon humour rappelle celui de Cromwell. Je dois aussi beaucoup à Christophe Colomb: car l'esprit américain m'a parfois frappé l'épaule, et j'en ai senti, avec joie, la morsure ironiquement glacée." 24 I believe it is highly likely that there is an element of this "morsure ironiquement glacée" present in the Note.

John Cage is, however, to bemoan the fact that "so much in Satie's writing leads people to believe that he was simply a humorist who was saying funny things without their having an otherwise useful meaning." 25 As I have endeavoured to show above, in common with many of his musical instructions, there seems to be some sort of figurative meaning underlying the ironic or enigmatic exterior of the Note de l'auteur in Vexations. I consider this meaning to hinge on the three "themes" touched on in the Note: immobility, silence and multiple repetition. It may well be true that in instructing the pianist to make preparations for playing the piece "par des immobilités sérieuses" the composer is calling for them to get into a state of "interior immobility." What I do not consider to be the case, however, is that Satie wants them to get into this state in preparation for a Zen-like expansion of consciousness. It would seem more likely - given Satie's artistic standpoint - that this "interior immobility" serves to prepare the interpreter for the "immobile" nature of the music, that is to play it in a manner which respects and enhances the anti-developmental qualities I have mentioned earlier so as to achieve Satie's aim of creating "une musique hors du temps." The problem with this interpretation, however, and one which I will address shortly, is that it leads to the question of why Satie should have been so keen to prepare his interpreters for the immobility of the music when, given its extreme repetitiveness, it is virtually impossible to play it any other way.

The instruction that this preparation should be carried out in the utmost silence is of symbolic significance also. For if Satie's music is intended to be a brief glimpse of something eternal, then it must emerge inconspicuously from an initial state of silence and return to it in the same way. As Jean-Joel Barbier says of the Gnossiennes,

23 Volta, Erik Satie: Écrits, nos. 11 and 23.

24 Ibid., 142.

25Cage, Shattuck, Gillmor, "Erik Satie: A Conversation," 21. 
Le vide est autour de cette musique [...] Elle sort du silence, et elle rentre dans le silence sans que le silence en ait été terni. [...] C'est dans cette restitution totale du silence qu'est son éternité. ${ }^{26}$

The silent preparation, whether taken literally or figuratively, is only a pointer towards a silence inherent in Satie's music (one of the instructions in his Prélude de la Porte Héroique du Ciel runs "Très sincèrement silencieux") and which the interpreter must bring out during performance in order to give the music its timeless quality. Bearing in mind these references to immobility and to silence, the Note seems to be saying the same thing although in a more expressive manner as the heading of the first prelude of Le Fils des Etoiles, "En blanc et immobile," whiteness being to colour what silence is to music.

As regard the third of the "themes" touched on in the Note, the repetition of the motif 840 times, I am not convinced that Satie intended a literal interpretation. Rather, as with the marking perpétuel in Le Tango from Sports et Divertissements, I believe that this instruction is making a figurative reference to the idea of eternity, in this case to the impression of eternity which the immobility of his pieces aims to evoke and which is the reason for the freshness and spontaneity of his music. This would tie in with Fred Goldbeck's remark in the edition of Contrepoints in which Vexations was first reproduced (volume $6,1949)$ that the piece "semble poser en principe que l'infini commence immédiatement après la 840 ème reprise, et peut-être même un peu avant." It is certainly by no means unusual that Satie should have used a finite number to express infinity. This is characteristic both of Eastern culture (in which, for example, an expression such as "may he live for a thousand years" is a reference to immortality rather than to extreme longevity) and of Biblical writing (for example, Christ in the Gospels uses the figure of 490 , that is $7 \mathrm{x}$ 70 , to express infinity), ${ }^{27}$ both of which were strong in Satie's mind during this period. How he arrived at the number 840 can only be a matter of speculation. Robert Orledge, for example, sees significance in the fact that 840 repetitions each lasting one minute would take exactly fourteen hours. My own guess is that he chose 840 because it is large enough to imply infinity and because it is divisible by three numbers that were of great symbolic importance to him: 3 (three persons in the Trinity, three Gymnopédies, Gnossiennes, Sarabandes etc.); 4 (four Gospels, four pieces in Ogives, En Habit de cheval, Préludes flasques) and 7 (seven deadly sins, seven pieces in Messe des pauvres, Trois Morceaux en forme de poire, Le Piège de Méduse). ${ }^{28}$

It is clear that in order to uncover Satie's intentions in writing Vexations there are many factors other than the obvious musicological ones that need to be taken into account. These encompass the opinions of his friends, followers

26Barbier, Au Piano avec Erik Satie, 41-43.

27 Matthew 18.21-22.

28 In his recent article "Understanding Satie's Vexations" in Music and Letters 79, no. 3 (August 1998): 386-395, Robert Orledge expresses a similar viewpoint, although relating the numbers 3,4 and 7 to aspects within the piece (p. 394). Orledge would furthermore concur with the idea that in choosing 840 Satie is making a reference to eternity, although for spiritual rather than aesthetic reasons (p. 394 also). 
and critics, circumstantial and semantic evidence, and literary elements relating to his use of figurative language within the context of his musical instructions, and his use of leitmotifs throughout his writings. Whilst accepting that from a position of over a hundred years after the compositional event one can only surmise at Satie's intentions, if indeed he did have any clear intentions at all, I believe there is only one hypothesis which would fit in with all the evidence I have detailed here. That is that Vexations is not a performance piece at all. Rather it is an exercise piece, or as I have suggested above, an "immobility exercise," a musical passage with neither beginning nor end, with neither direction nor destination, designed to prepare his interpreters both mentally and physically before a performance of a piece such as a Gymnopédie or a Gnossienne. And as with athletic exercises, it is up to the interpreter to decide how many exercises are required to get them into the right condition-" 840 times" is perhaps another way of saying "as many as it takes." It is as Bryars has pointed out a motif rather than a morceau, something which is not meant to stand on its own, but rather to hint at the longer, potentially infinite work to which it belongs and thereby draw attention to the infinite work to which all Satie's morceaux belong. It is not a literal expression of his artistic thinking but a reductio ad absurdum of it, seeking to pull his interpreters abruptly away from ideas of linear development and cumulative reception and towards his own non-developmental type of music. Vexations, then, is to Satie's musical output what the Note de l'auteur is to the Cagean concept of a "full" performance. Or perhaps it would be better to say that it is a musical instruction written in music rather than in words, a means of communicating to his interpreters in the language he knew best, not the spirit of any single work but the essence of his artistic philosophy.

It is interesting that the two men to whom we owe the most for Vexations' current renown should have had such differing opinions as to its value. Henri Sauguet, who acquired the manuscript after Satie's death and who had it published, thought it was nothing more than fumiste posturing. And John Cage, who did more than anyone else to publicize the piece, believed sincerely in its conceptual message. However, as I have shown in this section, I believe the answer to the enigma of the Note lies in steering a middle course between these two views. To describe what I mean I hope I may be permitted to draw on Satie's own inimitable imagery. In an ironic article entitled "Eloge des Critiques" Satie writes that the critic "ne rit que d'un œil" and that he is "un homme sérieux, sérieux comme un Bouddha, un boudin noir, évidemment."29 In his Note de l'auteur Satie is being neither sérieux comme un Bouddha, presenting us with a Zen-like exercise in self-discovery, nor sérieux comme un boudin noir, presenting a fumiste challenge to bourgeois values. Rather, he is "laughing with only one eye open": beneath the eccentric exterior the Note contains a serious request to the interpreter to join him in his quest to write "une musique hors de temps." 


\section{Abstract}

Erik Satie's piano piece Vexations contains a Note de l'auteur in which the composer apparently instructs his interpreters to repeat the piece 840 times. Opinion among Satie's biographers is divided as to whether Satie intended a "full" performance of the piece. In this article I assess how a literary interpretation of the Note can throw light on Satie's intentions. My conclusion is that Vexations is not so much a performance piece as an exercise piece: a musical passage designed to pull his interpreters away from conventional Western notions of linear development and cumulative reception and towards his own non-developmental style of music, in preparation for a performance of a piece such as a Gymnopédie or a Gnossienne.

\section{Résumé}

La pièce pour piano Vexations d'Erik Satie comporte une " Note de l'auteur » où le compositeur demande apparemment aux interprètes de répéter le morceau 840 fois. Les opinions des biographes de Satie divergent quant à savoir si Satie voulait ou non une exécution « complète » de la pièce. Dans cet article, l'auteur évalue comment une interprétation littéraire de la Note peut jeter un éclairage sur les intentions de Satie. Il conclut que Vexations n'est pas tant un morceau de bravoure qu'un exercice : un moment musical conçu pour dégager les interprètes des notions occidentales conventionnelles de développement linéaire et de réception cumulative, en faveur d'un style musical personnel d'où est absent le développement, et pour les préparer à jouer d'autres pièces, telles une Gymnopédie ou une Gnossienne. 